DEPÓSITO LEGAL ZU2020000153

Esta publicación científica en formato digital

es continuidad de la revista impresa

ISSN 0041-8811

E-ISSN 2665-0428

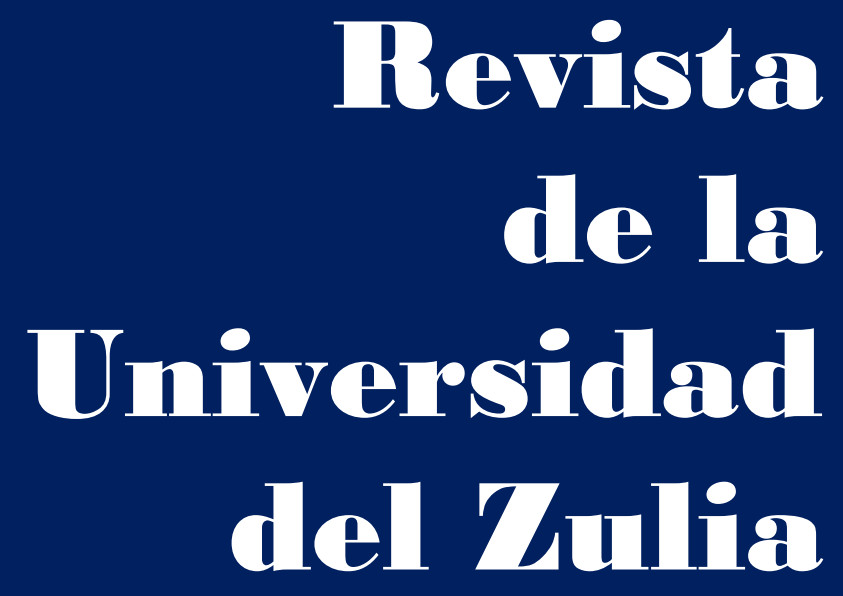

Fundada en 1947

por el Dr. Jesús Emrique Lossada

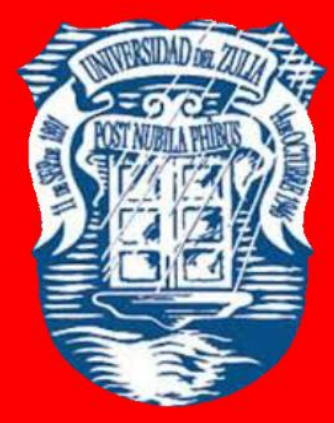

Ciencias

Sociales

y Arte

Año $12 \quad N^{\circ} 34$

Septiembre - Diciembre 2021

Tercera Época

Maracaibo-Veneruela 


\title{
Essence and structure of the readiness of future primary school teachers to design the learning environment
}

\author{
Karina Oleksenko * \\ Irina Khavina **
}

\begin{abstract}
The purpose of the study is to determine the essence of the preparation of future primary school teachers to design the learning environment in the operation of the new Ukrainian school. The application of methods that helped to carry out theoretical research: analysis and synthesis, systematization of materials, historical and logical, comparative, systemic and structural, allowed to study the essence of the preparation of future primary school teachers to design the learning environment in the New Ukraine School. This study allowed us to determine the essence of the preparation of future primary school teachers as specialists of the new generation, to design the learning environment of primary school students. The preparation structure of future primary school teachers is determined to design the learning environment and the content of its main constructs is specified, namely: the motivational, cognitive, operational-active and emotional-volitional components.
\end{abstract}

KEY WORDS: primary school; design; Learning environment; teacher attitudes.

* Dmytro Motornyi Tavria State Agrotechnological University, Melitopol, Ukraine. ORCID: https://orcid.org/0000-0002-2965-5145. E-mail: karinessa48@gmail.com

**National Technical University Kharkiv Polytechnic Institute, Kharkiv, Ukraine. ORCID: https://orcid.org/0000-0001-9038-0892. E-mail: irinakhavina@gmail.com 


\section{Esencia y estructura de la preparación de los futuros profesores de primaria para diseñar el entorno de aprendizaje}

RESUMEN

El propósito del estudio es determinar la esencia de la preparación de los futuros maestros de escuela primaria para diseñar el entorno de aprendizaje en el funcionamiento de la nueva escuela ucraniana. La aplicación de métodos que ayudaron a realizar investigaciones teóricas: análisis y síntesis, sistematización de materiales, histórico y lógico, comparativo, sistémico y estructural, permitió estudiar la esencia de la preparación de los futuros maestros de escuela primaria para diseñar el entorno de aprendizaje en la Nueva Escuela Ucrania. Este estudio nos permitió determinar la esencia de la preparación de los futuros maestros de la escuela primaria como especialistas de la nueva generación, para diseñar el entorno de aprendizaje de los estudiantes de la escuela primaria. Se determina la estructura de preparación de los futuros profesores de primaria para diseñar el entorno de aprendizaje y se especifica el contenido de sus principales constructos, a saber: los componentes motivacional, cognitivo, operacional-activo y emocional-volitivo.

PALABRAS CLAVE: escuela primaria; diseño; ambiente de aprendizaje; actitudes del maestro.

\section{Introduction}

Ukraine's integration into the world educational space requires continuous improvement of the national education system, particularly primary education, which is due to a number of orders of the Ministry of Education and Science of Ukraine and state regulatory documents, which declare the requirements for the educational process of elementary school, professional and pedagogical activity and personality of a new generation teacher - the Law of Ukraine "On Higher Education" (2014), "On Education" (2017), the Concept of the New Ukrainian School (2017), the Concept of Teacher Education Development (2018), the State Standard of Primary Education (2018) and others.

Now of particular importance is the idea of creating a learning environment that can provide a set of opportunities for all subjects of the educational process for self-development. The success of this process will affect the quality of training of primary education applicants and the professional activities of the new type of teacher, who should be distinguished by holistic, innovative thinking, goal-oriented behavior, research activity, the ability to make 
balanced and constructive decisions.

The problem of professional training of future primary school teachers is variously revealed in scientific research, in particular in recent years: "Preparation of future primary school teachers for orthoepic work in a trilingual learning environment" (Sheremet, 2015); "Preparing future teachers to create a healthy primary school environment" (Osadchenko, 2016); "Preparation of future teachers for the development of creative potential of junior schoolchildren by means of art therapy" (Kovinko, 2018); "Pedagogical conditions of preparation of future primary school teachers for communicative and speech development of students" (Shalivska, 2018); "Preparation of future teachers for modeling a lesson in the conditions of variability of primary education" (Nesterenko, 2019) and other.

However, the formation of the readiness of future elementary school teachers to design the learning environment in the implementation of the objectives of the New Ukrainian School Concept is still relevant for the present and requires further study.

The aim of the study: is to theoretically justify the essence and basic readiness constructs of future elementary school teachers to design the learning environment.

The objectives of the study: to consider the essence of readiness to design the learning environment; to identify and characterize the structural components of the readiness of future elementary school teachers to design the learning environment.

\section{Theory and methodology of the research}

Of special importance for our study are the achievements of researchers concerning the readiness of future elementary school teachers in the context of mastering professional activity. Thus scientists define readiness as: integrated personal education, which includes a set of psychological and pedagogical, informational and methodological knowledge and skills, as well as personal qualities necessary for effective use of information and communication technologies in the educational process (structure covers motivationalvaluable, cognitive, operational-activational, reflexive and evaluative components) (Andriyevska, 2019; Tigrov, 2021); holistic integrated personality quality of a future elementary school teacher, characterizes his motivation for communicative and speech students development, the combination of knowledge, skills and abilities to develop communicative and speech activity of elementary school students and ensuring 
communicative and speech students development in the process of professional and pedagogical activity (structure covers motivational and value, cognitive, activity and technological and productive components) (Shalivska, 2018); complex personal formation in the structure of which the motivational, cognitive, communicative and active, reflexive components are distinguished (Sheremet, 2015); the persistent integrative personalprofessional ability of a future teacher, characterized by the presence of motivation to develop the creative potential of younger students, personal-professional qualities, acquired knowledge, abilities and skills, including creative self-development and reflex (structure covers motivational-valuable, content, procedural, personal-reflexive components) (Kovinko, 2018), and others.

Researchers have considered the processes of modeling and designing a certain type of environment in the primary education applicants' training, which are components of future teachers' professional competence. M. Nesterenko clarifies the essence of the concept "design-modeling competence of future elementary school teachers", which acts as a reference result their professional training, is the awareness of pedagogical modeling personally important for their own professional activity, ability to model the lesson in a variable elementary education conditions (to plan, select resources, design a model), to reflect on the implementation of the pedagogical concept, the desire for self-development and self-improvement (Nesterenko, 2019). T. Osadchenko introduces the concept of "health preserving competence of a future elementary school teacher", is interpreted as a component formation in the structure of his professional competence, unites in one motives of professional and health preserving activity, the system of knowledge and skills of organizing the interaction of "teacher - student - parents" on the basis of health saving, the optimal combination of which on the basis of personal qualities, acquired experience and aspiration for professional self-development provides readiness and ability of a future teacher to create a health-saving elementary school environment (Osadchenko, 2016) and others.

Based on the analysis of scientific research, psychological and pedagogical literature and legal documents, the definition of the essence of readiness to design a learning environment is formulated. A content analysis was conducted to clarify and specify the conceptual and categorical apparatus for understanding the constructs of readiness of future primary school teachers to design the learning environment. 
So, the main feature of readiness for professional activity is its integrative nature, which manifests itself in the internal structures orderliness, coherence of the main professional personality components, in sustainability, stability and continuity of their functioning. As an integral formation, readiness reflects a holistic state of a personality, including not only the presence of abilities and qualities necessary in future activity, but also attitude towards it, which is manifested in needs, desires, motives. Readiness for activity develops on the basis of assimilation of general and professional knowledge, abilities and skills formation, perfection of established professionally important personal qualities.

In determining the structure and content of the readiness of future elementary school teachers to design the learning environment we took into account:

- requirements for professional competence of an elementary school teacher (ability to pedagogical activity, organization of the educational process in the elementary school at the modern requirements level, ability to act effectively, effectively solve standard and problematic professional tasks arising in the teaching process, education and development of elementary school students), whose basis is the unity of theoretical and practical readiness to carry out pedagogical activities, which is manifested in the presence of systems, knowledge, skills, value attitudes to professional activity and the experience of their implementation in practice;

- professional pedagogical competencies (didactic, educational, organizational) and their correlation with the competency classification of the National Qualifications Framework (Osadchenko, 2016).

- the operation system (abilities and skills, knowledge and understanding) required to perform professional tasks;

- the peculiarities of projecting activity, found in the goals, process and results

- the peculiarities of the personal readiness phenomenon, connected with the intellectual, emotional, reflexive, volitional, motivational and activity spheres;

- dynamic model of personality structure within the framework of system-activity approach by K. Platonov, which contains substructures of directionality, experience, forms of reflection and biological conditionality.

\section{The results of the study}

Designing as a project creation activity is characterized by two things: the ideal nature 
of the action and its focus on the appearance of something in the future. These two characteristics distinguish designing from other types of activity (Sosnytska, Kryvylova, Oleksenko, 2020).

Designing the learning environment is an important professional task of future elementary school teachers, which requires a daily solution in the conditions of the real educational process.

The main requirements for designing students' learning environment and the latest guidelines in the preparation of future elementary school teachers for the specified activity are:

- The learning environment as an object of design reflects the relationship of certain conditions of organized, two-way activity of the teacher and students aimed at the maximum assimilation and awareness of the educational material and further application of the acquired knowledge, skills and abilities in practice (Cabrera et al, 2020);

- the methodological foundations for designing the learning environment are: competency-based approach - organizing the learning process in order to form key, subject and life competencies; integrative approach - taking into account internal subject and interdisciplinary links, maximum overcoming of isolated teaching of subjects and creating fundamentally new educational programs; research-based approach - using research forms, methods and means of learning; person-centered approach - directing the learning process to the following

- understanding of the modern lesson as a project to create real conditions for the intellectual, social, moral formation of the students' personality, allows to achieve high results in learning, the process of which is built on three basic types of activity: learning (mastering cultural samples, existing knowledge, conceptual positions) practice (acquisition of skills, methods of activity); research and design (entering the subjective position in relation to reality).

- clear structuring of the interaction of participants in the educational process, which will contribute to the development of independent learning activities of students: awareness of their own role in solving learning tasks; presence of purpose, motivation and activity of implementation of activities; planning of future work, identifying its results and awareness of ways in which you can get new knowledge and skills, identify common ways of action; 
control over their actions, ways of their implementation and evaluation; seeing the importance of the mastered experience, knowledge, skills, acquired personal qualities for achieving the goal;

- formation of specific professionally important qualities of future elementary school teachers to design students' learning environment: problem vision, creativity, persistence, tolerance for mistakes, tolerance, openness, accessibility and flexibility (Radyonova, S. Savelova, S. Philosophical Dictionary: the largest collection of online dictionaries).

The analysis of scientific research on the essence and structure of future specialists' readiness for various aspects of professional activity indicates the importance of motivational, cognitive, operational-activational and emotional-volitional components.

Motivation is a set of external and internal driving forces that motivate the activity and give it orientation, focused on achieving a certain goal. The development of positive learning motivation in future elementary school teachers is a condition for personal development and effective professional training. Among the various motives of learning there are internal and external. Internal motives are associated with cognitive need, pleasure from the process of learning and are characterized by activity at the stage of professional formation. External motives are associated with the needs, which are focused on material benefits, the prestige of the chosen profession, recognition and reveal a positive or negative attitude to obtain the expected result of the activity. That is, future elementary school teachers, in addition to the motivation for success, may focus on the negatives, failures and punishments in the process of mastering the specialty. In this case we can not talk about the full development of personality and formation of a professional. Inadequacy of motives of learning activity can be the reason of insufficient preparation for professional activity.

So, the motivational component of the readiness of future elementary school teachers to design learning environments is characterized as: established cognitive need to master the projective activity; interest in the process of creating a learning environment; sustained desire to update and enrich knowledge on the development of primary education based on the ideas of the Concept of the New Ukrainian School.

The cognitive component of readiness for any activity includes understanding of certain tasks, knowledge of the ways to solve them and the means of achieving the goal, analysis of possible changes in the situation. The challenges of time imply a change not so 
much in the content and tools of pedagogical activity, as in thinking. The skills of integrative thinking allow solving professional problems effectively. One of the main characteristics of integrative thinking is consistency. The knowledge formed as a result of integrative thinking also have this property. Systemic knowledge ensures the ability of future elementary school teachers to identify, install, study the existing structural relations of pedagogical phenomena; the ability to see the studied phenomena in the dynamics of development; the ability to predict and model further possible transformations of phenomena. Thus, integrative thinking, its formation in future elementary school teachers is an objective necessity due to the rapid transformation of various factors in the field of education. Cognitive activity organically combines both already acquired experience (knowledge, mental skills and abilities) and the ability of further independent assimilation and application in practice. The quality of knowledge (flexibility, strength, understanding), as one of the main indicators of professional training, is central to the evaluation of both theoretical and practical learning.

Thus, the content of the cognitive component of the readiness of future elementary school teachers to design the learning environment reflects the developed properties of integrative thinking that meet the requirements of projective activity; understanding of the features of the learning environment of primary education applicants and the process of its design.

The readiness of future elementary school teachers to design the learning environment involves operating with all the necessary techniques for obtaining and processing professional information. For example, future teachers of elementary school should operate with basic didactic concepts; apply in school practice different approaches to the organization of the educational process of primary education applicants (students); distinguish types of lessons by structure and use them in accordance with the didactic purpose; comply with the basic requirements for a modern lesson; To know the methods and methods of stimulation of educational-cognitive interests of students; to determine the ways of optimization of educational activity of students; to be able to organize independent educational-research activity of students; to carry out didactic analysis of a lesson at elementary school; to apply forms and methods of diagnostics of learning results; to possess the skills of control and evaluation of educational achievements of students and so on. Of particular importance is the ability and readiness to carry out a purposeful sequence of 
actions to synthesize systems or their individual components, the development of documentation necessary to implement and use objects and processes; the ability to design, construct and model pedagogical situations.

Thus, the operational-activational component of future elementary school teachers' readiness to design learning environments is characterized by the ability to create learning environments taking into account the elementary education variability and educational process resources.

Designing the learning environment successfully depends on the level of formation of the emotional-will component of the elementary school teachers' readiness. Will is the ability to self-determination and self-regulation of activity and various mental processes. The volitional personality features include self-control, endurance, patience, persistence, determination, courage, criticality (Fundamentals of Psychology). Will is manifested when a future specialist meets difficulties on the goal realization way. The final stage of will manifestation is actions related to overcoming internal or external obstacles. The importance of the emotional sphere of education applicants is noted in the Concept of the New Ukrainian School, where emotional intelligence is highlighted as one of the areas with which each graduate should be familiarized. Emotions reflect the attitude of future elementary school teachers to the world around them, to other participants in the educational process, to themselves and to their own activity results. Designing the learning environment is a rather complex, multidimensional and multifaceted process. It requires complex regulation of a whole complex of mental processes, properties, and states. For successful projective activity future elementary school teachers should know and masterfully use their emotional and sensual potential.

So, the emotional-volitional component of the readiness of future elementary school teachers to design the learning environment is characterized by awareness of their own emotional-volitional capabilities; force mobilization during the design activity; responsibility for making professional decisions to create the learning environment of elementary education applicants.

Based on the psycho-pedagogical research analysis, we interpret the concept "readiness of future elementary school teachers to design the learning environment" as a sustainable state of readiness to successfully create real conditions for intellectual, social, 
moral formation of elementary education applicants, based on the mobilization of potential capabilities (motivational, operational-activity, cognitive, emotional-will) and experience, in order to obtain the expected result and further personal development in a changing environment.

\section{Conclusions}

Therefore, based on the analysis of regulatory documents, psychological and pedagogical literature and scientific research, the essence of readiness to design the learning environment of primary school applicants and for the first time formulated its interpretation in the professional formation context of future elementary school teachers as a new generation of specialists in the New Ukrainian school. Defined the structure of the readiness of future elementary school teachers to design learning environments and clarified the content of its main components, such as motivational, cognitive, operational-activational and emotional-volitional components.

For the first time, the interpretation of the readiness of future primary school teachers to design the learning environment is formulated, its structure is determined and the content of the main components - motivational, cognitive, operational and emotional and volitional is specified.

The prospect of further research in this direction is associated with the development of a model for the formation of future elementary school teachers' readiness to design the learning environment.

\section{References}

About coverage: Law of Ukraine dated 09/05/2017. No. 38-39. Recovered from URL: http://zakon.rada.gov.ua/laws/show/2145-19

About the concept of realizing state policy in the sphere of reforming the home middle education "New Ukrainian School" for the period up to 2029: order of the Cabinet of Ministers of Ukraine No. 988 dated 14 March 2016. Recovered from URL: https://zakon.rada.gov.ua/laws/show/988-2016-p\#Text

About the consolidated concept of development of pedagogical education: mandate of the Ministry of Education and Science of Ukraine dated July 16, 2018. No. 776 Recovered from URL: https:/mon.gov.ua/ua/npa/pro-zatverdzhennya-koncepciyi-rozvitkupedagogichnoyi-osviti 
About the consolidation of the national framework of qualifications: Resolution of the Cabinet of the Ministries of Ukraine No. 1341 dated 23.11.201lr Recovered from URL: http://zakon4.rada.gov.ua/laws/show/1341-2011-ח

About vision of education: Law of Ukraine dated 01.07.2014 No. 1556-VII. Recovered from URL : http://vnz.org.ua/zakonodavstvo/lll-zakon-ukrayiny-pro-vyschu-osvit

Andriyevska, V. M (2019). Theoretical and methodical bases of preparation of the future teacher of elementary school for use of information and communication technologies in professional activity. Extended abstract of candidate's thesis. Kharkiv [in Ukrainian]

Cabrera Zurita, A., Ríos Campos, C., Camacho Delgado, F., Sánchez Medina, G., Ríos Campos, P., Estela Urbina, R., \& Gutiérrez Valverde, K. (2020). Resolución de problemas en cuatro pasos como proyección didáctica en el contexto de la enseñanza de la Física. Revista Latinoamericana De Difusión Científica, 2(3), 39-71. https://doi.org/10.38186/difcie.23.05

Fundamentals of Psychology. Recovered from URL: https:/pidruchniki.com/1931071037363/psihologiya/emotsiyi pochuttya

Kovinko, A.V. (2018). Preparation of future teachers for the development of creative potential of junior schoolchildren by means of art - therapy. Extended abstract of candidate's thesis. Kharkiv [in Ukrainian]

Nesterenko, M. M. (2019). Preparation of future teachers for modeling a lesson in the conditions of variability of primary education. Extended abstract of candidate's thesis. Berdiansk [in Ukrainian]

Osadchenko, T. M. (2016). Preparing future teachers to create a healthy primary school environment. Extended abstract of candidate's thesis. Zhytomyr, [in Ukrainian]

Radyonova, S., Savelova, S. Philosophical Dictionary: the largest collection of online dictionaries. $\quad$ Recovered from URL: http://www.onlinedics.ru/slovar/fil/p/proektirovanie.html

Shalivska, Yu. V. (2018). Pedagogical conditions of preparation of future primary school teachers for communicative and speech development of students. Extended abstract of candidate's thesis. Rivne [in Ukrainian]

Sheremet, O. V. (2015). Preparation of future primary school teachers for orthoepic work in a trilingual learning environment. Extended abstract of candidate's thesis.Kherson [in Ukrainian]

Sosnytska, N., Kryvylova, O., Oleksenko, K. (2020). The design of the beginning middle school is the professional task of the future teachers of the cob school. Education of Ukraine in the context of civilization changes and victories: camp, problems, perspectives of development "International scientific and technical university of the name of academician Yuriya Bugai". Kiev: Fenix, 272-290. 


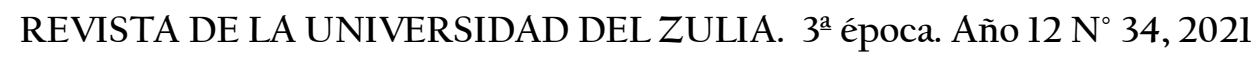
Karina Oleksenko \& Irina Khavina /// Essence and structure of the readiness of future primary ... 398-409 DOI: http://dx.doi.org/10.46925//rdluz.34.23

State standard of cob coverage: Resolution of the Cabinet of Ministers of Ukraine No. 87 dated 21.02.2018 p. $\quad$ Recovered from URL: http://dano.dp.ua/attachments/article/303/Державний\%20стандарт\%20початкової\%20 освіти.pdf

Tigrov, V., Tolstenko, A., Negrobova, L., Dobromyslova, O., \& Piminov, E. (2021). Education, work and creation: ways for developing technological education of schoolchildren in Russia. Amazonia Investiga, 10(42), 206-216. https://doi.org/10.34069/AI/2021.42.06.19 